\title{
Transformation Mechanism of Fluormica to Fluoramphibole in Fluoramphibole Glass Ceramics
}

\author{
Wei Si, ${ }^{1}$ Hua-Shen Xu, ${ }^{1}$ Ming Sun, ${ }^{1}$ Chao Ding, ${ }^{2}$ and Wei-Yi Zhang \\ ${ }^{1}$ School of Materials Science and Engineering, Dalian Jiaotong University, Dalian 116028, China \\ ${ }^{2}$ Dalian Environmental Monitoring Center, Dalian 116023, China \\ Correspondence should be addressed to Wei Si; siwei@djtu.edu.cn
}

Received 2 March 2016; Accepted 24 May 2016

Academic Editor: Santiago Garcia-Granda

Copyright (c) 2016 Wei Si et al. This is an open access article distributed under the Creative Commons Attribution License, which permits unrestricted use, distribution, and reproduction in any medium, provided the original work is properly cited.

During isothermal sintering at $820^{\circ} \mathrm{C}$, the transformation mechanism of fluormica to fluoramphibole in powder compacts of fluormica and soda-lime glass was investigated using differential thermal analysis, infrared reflection spectrometry, Xray diffraction, scanning electron microscopy, and so forth. Results show that an interaction between fluormica and glass occurred during isothermal heating; $\mathrm{O}^{2-}, \mathrm{Na}^{+}$, and $\mathrm{Ca}^{2+}$ ions were diffused from glass to fluormica. This diffusion facilitates the transformation of the sheet structures of fluormica crystals to double-chain structures by the breakage of bridge oxygen bonds in the sheet. Subsequently, the broken two parallel double chains were rearranged by relative displacement along the $c$-axis direction of the fluormica crystal and were linked by $\mathrm{Na}^{+}$and $\mathrm{Ca}^{2+}$ ions to form fluoramphibole. A crystallography model of fluormicafluoramphibole transformation was established in this study.

\section{Introduction}

The world's first fluoramphibole glass ceramic was prepared by Beall by using a melting method [1]. He successfully prepared potassium fluorrichterite by using a two-step heat treatment based on $\mathrm{K}_{2} \mathrm{O}-\mathrm{MgO}-\mathrm{Al}_{2} \mathrm{O}_{3}-\mathrm{SiO}_{2}-\mathrm{F}$ fluormica glass ceramic formulation with $\mathrm{CaO}, \mathrm{NaO}, \mathrm{Li}_{2} \mathrm{O}, \mathrm{BaO}$, and $\mathrm{P}_{2} \mathrm{O}_{5}$. Results showed that the transition phase tetrasilicic fluormica and diopside were first precipitated from the parent phase glass and then a reaction occurred with the parent phase glass and formed fluoramphibole during the high-temperature crystallization process $[2,3]$.

The traditional production model of glass ceramics has been a "one-to-one" process; that is, to obtain a desired glass ceramic, a batch of parent glass with the specific components should be melted [4-6]. The "one-to-multiple" preparation model of glass ceramics by the direct reactive crystallization of common soda-lime glass and the added crystal becomes a new research method. We have proposed a novel route called sintering-reactive crystallization to fabricate a series of different types of glass ceramics by using the waste soda-lime glass powder as the main raw material, adding different silicate crystals into the glass powder, and sintering. Fluoramphibole glass ceramics have wide applications in environmental protection building materials because they possess good machinability $[7,8]$. This technique can be used for low-cost production without melting glass with the specific components and can significantly reduce sintering temperature and energy consumption.

The effect of promoter components, additions, and sintering temperatures on the crystallization, microstructures, and mechanical properties of fluoramphibole glass ceramics were studied in detail [9]. However, the mechanism to transform fluormica crystals into fluoramphibole crystals is rarely reported. The present study aims to establish a crystallography model of the polysomatic transformation of silicate crystals from fluormica to fluoramphibole.

\section{Experimental}

2.1. Preparation. Commercially available fluormica powder (size of 130 mesh) (Dashiqiao Chemical Plant, Liaoning, China) was used. The chemical composition of this fluormica was $6.33 \% \mathrm{~K}, 15.12 \% \mathrm{Mg}, 5.01 \% \mathrm{Al}, 19.69 \% \mathrm{Si}, 43.48 \% \mathrm{O}$, and 
$10.36 \% \mathrm{~F}$ by weight, close to the stoichiometric composition of fluorphlogopite $\left(\mathrm{KMg}_{3} \mathrm{AlSi}_{3} \mathrm{O}_{10} \mathrm{~F}_{2}\right)$. The recycled window glass was used as the base glass. Its composition was $71.3 \%$ $\mathrm{SiO}_{2}, 9.8 \% \mathrm{CaO}, 13.3 \% \mathrm{Na}_{2} \mathrm{O}, 4.3 \% \mathrm{MgO}, 1.0 \% \mathrm{Al}_{2} \mathrm{O}_{3}$, and $0.3 \% \mathrm{~K}_{2} \mathrm{O}$ by weight, and its size was 100 mesh.

Two types of sample were prepared. (1) Mixed sample: the fluormica crystal (35 wt\%) and recycled glass (65 wt $\%$ ) powder mixtures were ball-milled for $4 \mathrm{~h}$. Thereafter, 3 drops of $6 \mathrm{wt} \%$ PVA water solution was added as a binder. Finally, the mixtures were pressed in a hardened steel die to create cylindrical compacts with $15 \mathrm{~mm}$ diameter and $15 \mathrm{~mm}$ thickness. (2) Sandwich sample: in this sample, a thin fluormica powder layer (thickness of about $1 \mathrm{~mm}$ ) was embedded within two layers of glass powders. The sample was pressed in a hardened steel die to create cylindrical compacts with $15 \mathrm{~mm}$ diameter and $15 \mathrm{~mm}$ thickness. The compacts were presintered at $400^{\circ} \mathrm{C}$ for $2 \mathrm{~h}$ to remove the binder and then sintered from room temperature to $820^{\circ} \mathrm{C}$ at different time durations to obtain the final glass ceramics.

2.2. Characterization. The crystallization reaction temperature of the glass and fluormica powders was identified by differential thermal analysis (DTA, STA449F3) at a heating rate of $10 \mathrm{~K} / \mathrm{min}$. The crystalline-precipitated type of sintered glass ceramics and the changes in the relative contents of fluormica during isothermal process were characterized by X-ray diffraction (XRD) (Rigaku $\mathrm{D}_{\mathrm{MAX}}-\mathrm{RB}$ ) with $\mathrm{Cu} \mathrm{K} \alpha$ radiation. The relative contents of fluormica were calculated according to the equation $I_{t} / I_{o}[10]$, where $I_{o}$ is the total strength of the five strongest peaks in fluormica XRD ( $d=$ $0.960,0.330,0.290,0.199$, and $0.167 \mathrm{~nm}$ ) before sintering and $I_{t}$ is the total strength of the above five strongest peaks in fluormica XRD at a certain sintered time during the isothermal process.

The changes in the chemical bonds of fluormica during the isothermal process were characterized by infrared reflection spectrometry (Nicolet-20DXB). The fractured surfaces of the sintered glass ceramics were coated with a thin film of gold and were observed by scanning electron microscopy (SEM) (JSM-6360LV). The fractured surfaces of the sandwich sample were polished and etched using $20 \%$ HF water solution for $30 \mathrm{~s}$, washed with deionized water, and dried. The changes of element contents around the glass and fluormica interface in the sandwich sample were characterized by energy dispersive spectrometer (Oxford-INCA). The high-resolution transmission electron microscopy (HRTEM), selected area electron diffraction, and fast Fourier transform of the products were characterized by a JEM-2100F operated at an accelerating voltage of $200 \mathrm{kV}$.

\section{Results and Discussion}

The DTA curve of mixed samples is shown in Figure 1. The endothermic peak was observed at $600^{\circ} \mathrm{C}$, thus showing the glass transition temperature. The smaller exothermic peak was observed at $823^{\circ} \mathrm{C}$, which is attributed to the reaction crystallization between the glass and fluormica.

Figure 2 shows the XRD patterns of samples isothermally heated at $820^{\circ} \mathrm{C}$. The main crystalline phase of the sample was

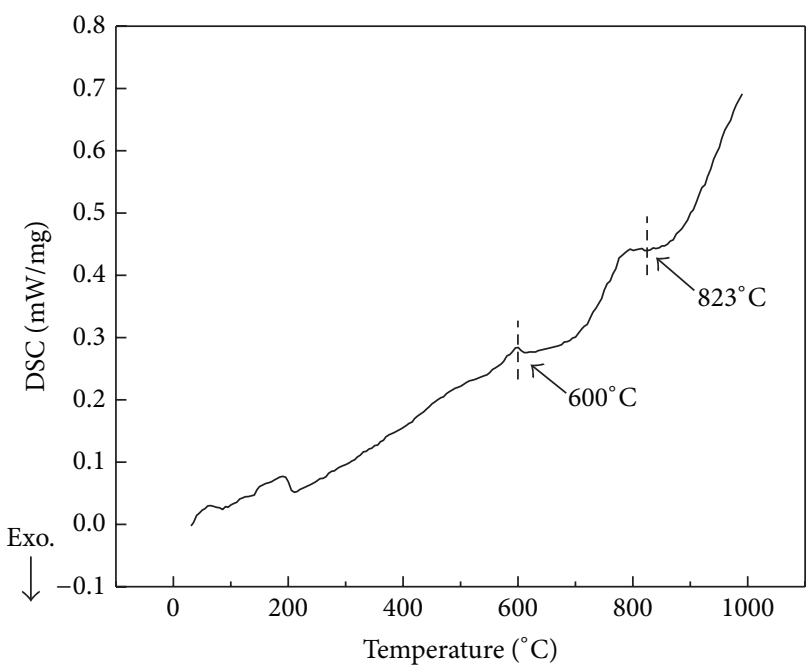

FIgURE 1: DTA curve of mixed samples.



- Fluormica

○ Fluoramphibole

FIGURE 2: XRD patterns of samples isothermally heated at $820^{\circ} \mathrm{C}$.

fluormica (JCPDS 16-0344) at room temperature $\left(20^{\circ} \mathrm{C}\right.$, not sintered) and heated at $820^{\circ} \mathrm{C}$, where no new crystalline phase formed. When isothermally heated at $820^{\circ} \mathrm{C}$ for $10 \mathrm{~min}$, the main crystalline phase was still fluormica, but the intensity of the diffraction peak decreased. However, some diffraction peaks disappeared. The weak peak of the fluoramphibole (JCPDS 41-1429) appeared because of annealing. These new fluoramphibole phases were the reactive crystallization products between fluormica crystals and glass powder during the sintering process but only had few precipitation contents. With increasing isothermal time, the diffraction peak intensity of fluormica continued to decline. After isothermal treatment for $4 \mathrm{~h}$, the diffraction peaks of fluormica almost completely disappeared and the main phase changed to fluoramphibole. 


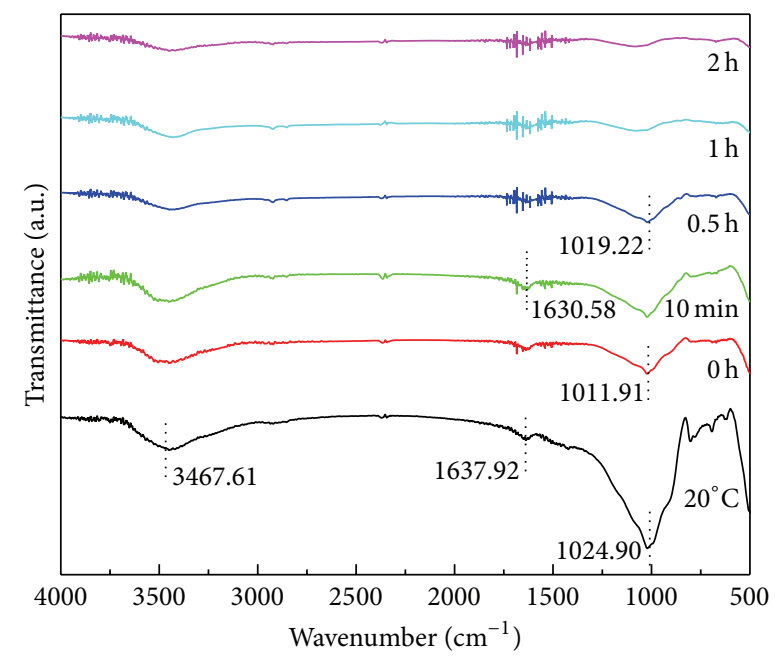

FIGURE 3: IR spectra of samples isothermally heated at $820^{\circ} \mathrm{C}$.

TABLE 1: Relative contents of fluormica in mixed samples isothermally heated at $820^{\circ} \mathrm{C}$.

\begin{tabular}{lcccccc}
\hline Time & $0 \mathrm{~h}$ & $10 \mathrm{~min}$ & $0.5 \mathrm{~h}$ & $1 \mathrm{~h}$ & $2 \mathrm{~h}$ & $4 \mathrm{~h}$ \\
\hline Relative content/\% & 91.8 & 58.8 & 56.7 & 46.5 & 39.3 & 5.36 \\
\hline
\end{tabular}

Table 1 shows the relative contents of fluormica in the mixed samples isothermally heated at $820^{\circ} \mathrm{C}$. Few fluormica started to decompose when the temperature increased to $820^{\circ} \mathrm{C}$. The fluormica decomposition rate increased with increasing isothermal time. The decomposition of fluormica was approximately $50 \%$ when the isothermal time was $1 \mathrm{~h}$. Fluormica was nearly completely decomposed after $4 \mathrm{~h}$.

Figure 3 shows the IR spectra of the samples isothermally heated at $820^{\circ} \mathrm{C}$ at different time points. At $20^{\circ} \mathrm{C}$ (before sintering), the wide band is due to the stretching of Si-O-Si; its maximum peak is at $1024.90 \mathrm{~cm}^{-1}$. The band at 640.72 and $3467.61 \mathrm{~cm}^{-1}$ indicates the presence of $\mathrm{O}-\mathrm{H}$ bond. All of the above peaks are characteristic peaks of fluormica.

The Si-O-Si bond weakened with increasing isothermal treatment time. This bond also has low strength when isothermally heated at $820^{\circ} \mathrm{C}$ for $2 \mathrm{~h}$. The Si-O-Si bond was gradually broken, and fluormica was continually decomposed during the isothermal process. This result is consistent with the above measured results of XRD.

The crystalline microstructures of the glass ceramics isothermally heated at $820^{\circ} \mathrm{C}$ for different time points are shown in Figure 4 . The microstructures of the sample contain the plate-like fluormica and glass phase when only heated at $820^{\circ} \mathrm{C}$ (Figure $4(\mathrm{a})$ ). After isothermal heating at $820^{\circ} \mathrm{C}$ for $10 \mathrm{~min}$, the sample was not sintered, whereas most of the glass particles were interconnected. The plate-like fluormica crystals were dispersed in the glass particles (Figure 4(b)).

After isothermal heating for $0.5 \mathrm{~h}$ (Figure 4(c)), a closed hole formed in the organization, and plate-like fluormica was surrounded by a glassy matrix. Among them, a little fine acicular fluoramphibole crystal was precipitated. After isothermal heating for $1 \mathrm{~h}$, dense acicular fluoramphibole crystals
TABLE 2: Composition change of sandwich samples isothermally heated at $820^{\circ} \mathrm{C}$ and $900^{\circ} \mathrm{C}$ (wt\%).

\begin{tabular}{lccccccc}
\hline & \multicolumn{3}{c}{$820^{\circ} \mathrm{C}$} & \multicolumn{3}{c}{$900^{\circ} \mathrm{C}$} \\
Element & \multicolumn{2}{c}{$0 \mathrm{~h}$} & \multicolumn{2}{c}{$0 \mathrm{~h}$} & \multicolumn{2}{c}{$\mathrm{h}$} \\
& $P_{1}$ & $P_{2}$ & $P_{3}$ & $P_{4}$ & $P_{5}$ & $P_{6}$ \\
\hline $\mathrm{O}$ & 29.44 & 19.74 & 35.80 & 52.93 & 39.36 & 45.65 \\
$\mathrm{Si}$ & 42.35 & 31.83 & 35.20 & 25.25 & 25.37 & 30.57 \\
$\mathrm{Na}$ & 8.34 & 2.27 & 4.38 & 7.15 & 3.50 & 8.18 \\
$\mathrm{Ca}$ & 9.00 & 3.04 & 5.69 & 7.70 & 1.96 & 4.39 \\
$\mathrm{~F}$ & 1.35 & 11.36 & 4.40 & 1.01 & 10.36 & 6.22 \\
$\mathrm{Mg}$ & 5.41 & 21.01 & 10.20 & 1.34 & 10.97 & 2.06 \\
$\mathrm{Al}$ & 1.72 & 5.59 & 1.67 & 1.52 & 4.40 & 1.41 \\
$\mathrm{~K}$ & 2.39 & 5.16 & 2.66 & 3.10 & 4.08 & 1.52 \\
\hline Total & 100.00 & 100.00 & 100.00 & 100.00 & 100.00 & 100.00 \\
\hline
\end{tabular}

appeared in closed pores; they were exerted from the edge of the glassy matrix (Figure 4(d)). With increasing isothermal timing, plate-like fluormica crystals completely disappeared and the interlace of circular fluoramphibole crystals within the pores further became rod-shaped (Figures 4(e) and 4(f)).

Figure 5 shows the microstructures of the interface in sandwich samples isothermally heated at $820^{\circ} \mathrm{C}$ for 0 (a) and $2 \mathrm{~h} \mathrm{(b)}$ and at $900^{\circ} \mathrm{C}$ for 0 (c) and $2 \mathrm{~h} \mathrm{(d).} \mathrm{The} \mathrm{obvious} \mathrm{interface}$ exists between the glass and fluormica when only heated at $820^{\circ} \mathrm{C}$ (indicated by the arrow in Figure 5(a)). After being isothermally heated at $820^{\circ} \mathrm{C}$ for $2 \mathrm{~h}$, the glass phase gradually leaked into fluormica by viscous flow. Thereafter, the fluoramphibole crystals were precipitated at the interface of the glass and fluormica, as shown by the arrows in Figure 5(b). According to the results of DTA and XRD, the above acicular crystal was the reaction crystallization product between the glass and fluormica. At $900^{\circ} \mathrm{C}$ isothermal heating, the crystal was precipitated to rod-like fluoramphibole crystals (Figure 5(c)). After isothermal heating at $900^{\circ} \mathrm{C}$ for $2 \mathrm{~h}$, the fluoramphibole crystals further increased in size and combined with the glass matrix (Figure 5(d)). Figure 5 shows the sizes of the rod-like crystals, and the amount of pores increased with the increasing sintering temperature and isothermal heating time.

Table 2 displays the composition change of microstructures near the interface isothermally heated at 820 and $900^{\circ} \mathrm{C}$ (for $P_{1}, P_{2}, P_{3}, P_{4}, P_{5}$, and $P_{6}$ in Figure 5). The raw materials showed that the glass does not contain any $\mathrm{F}$ elements and fluormica does not contain $\mathrm{Na}$ and $\mathrm{Ca}$ elements. When only heated to $820^{\circ} \mathrm{C}$ (Figure $5(\mathrm{a})$ ) or $900^{\circ} \mathrm{C}$ (Figure 5(c)), a small amount of $\mathrm{F}$ element was observed in the glassy side of the interface $\left(P_{1}, P_{4}\right)$, whose content was $1.35 \%$ and $1.01 \%$, respectively. After isothermal heating for $2 \mathrm{~h}\left(P_{3}, P_{6}\right)$, the contents of the $\mathrm{O}, \mathrm{Si}, \mathrm{Na}$, and $\mathrm{Ca}$ elements increased, whereas those of $\mathrm{F}, \mathrm{Mg}, \mathrm{Al}$, and $\mathrm{K}$ decreased. Therefore, these elements were reciprocally diffused between the glass and fluormica. The $\mathrm{O}^{2-}, \mathrm{Si}^{4+}, \mathrm{Na}^{+}$, and $\mathrm{Ca}^{2+}$ ions in the glass phase entered the fluormica phase through diffusion. The $\mathrm{F}^{-}, \mathrm{Mg}^{2+}, \mathrm{Al}^{3+}$, and $\mathrm{K}^{+}$ions also entered into the glass phase through the diffusion, and fluoramphibole crystals were subsequently precipitated. 

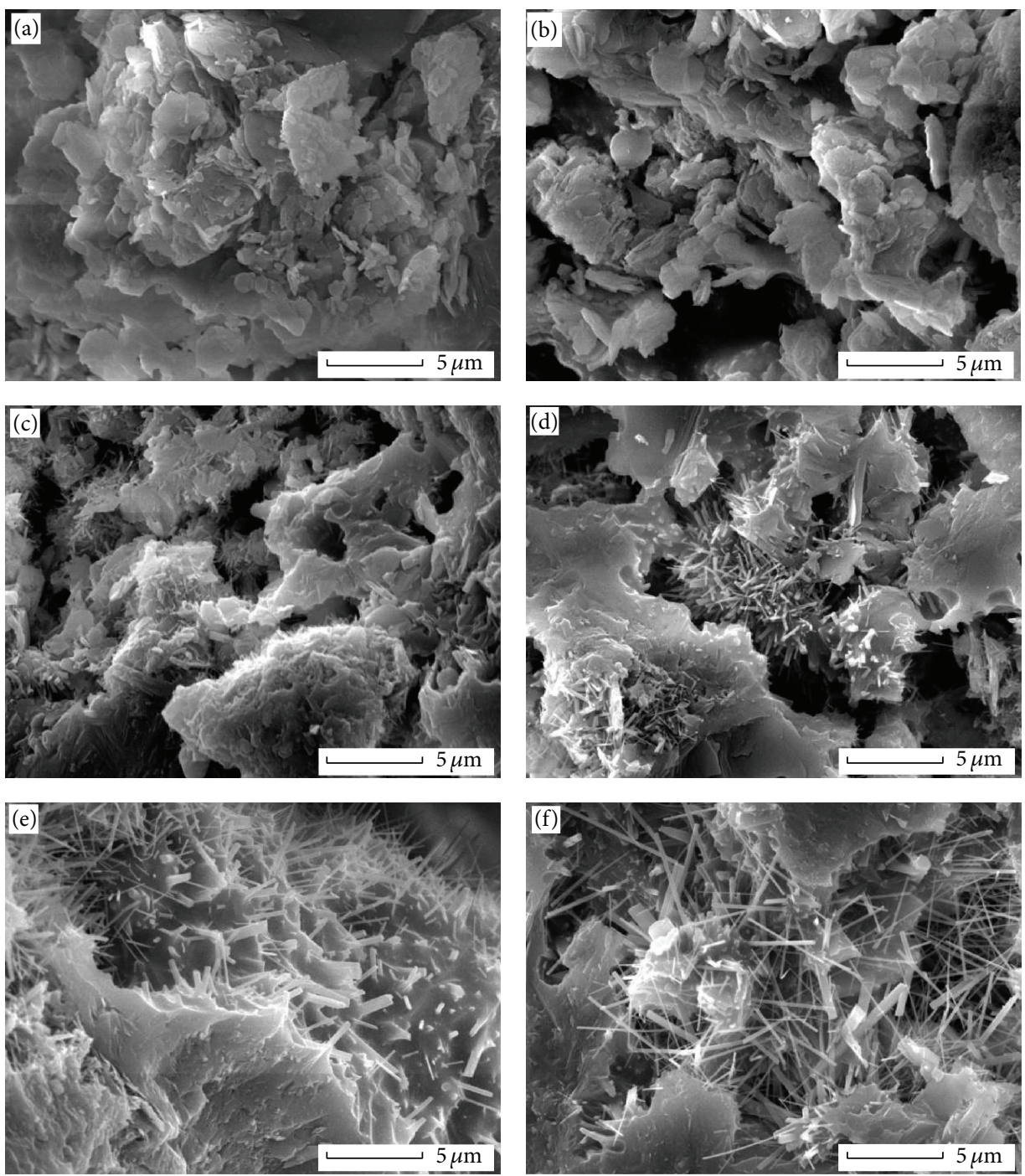

FIGURE 4: Microstructures of glass ceramic samples isothermally heated at $820^{\circ} \mathrm{C}$ with (a) $0 \mathrm{~h}$, (b) $10 \mathrm{~min}$, (c) $0.5 \mathrm{~h}$, (d) $1 \mathrm{~h}$, (e) $2 \mathrm{~h}$, and (f) $4 \mathrm{~h}$.

The above conclusion can be further illustrated by the SEM photographs of the sandwich samples after hydrofluoric acid etching. When using hydrofluoric acid etching, many pores formed in the glassy matrix because $\mathrm{SiF}_{4}$ was formed via a chemical reaction of $\mathrm{SiO}_{2}$ and HF; in this case, almost all rod-like fluoramphibole crystals were eluted (Figure 6(a), right illustration shows the enlarged area of the left red circle). The elution rod-like fluoramphibole crystals have smooth surfaces, and the length is above $40 \mu \mathrm{m}$ (Figure 6(b)). This observation further proved that the fluoramphibole crystals were indirectly precipitated from the fluormica crystal and formed by the interdiffusion between fluormica crystals and glass powder.

The transmission electron microscope (TEM) and HRTEM analyses were conducted on the glass part of the sandwich sample at $820^{\circ} \mathrm{C}$ isothermal heating for $2 \mathrm{~h}$. Precipitated crystal has a long rod-like shape (Figure 7(a)). A good crystallinity crystal in the glassy matrix, which is a single crystal, can also be observed. The measured $d$ value of the precipitated crystal is $0.267 \mathrm{~nm}$ (Figure 7(b)).

According to the XRD results, the $d$ value of the crystal plane (151) with the strongest diffraction peak of the fluoramphibole crystals is $0.269 \mathrm{~nm}$ (JCPDS 41-1429). These two results obtained from XRD and HRTEM analyses are consistent with each other; they show that the precipitated crystal is a fluoramphibole crystal. Based on the experimental results, crystallization reaction occurred between the components of recycled glass powder and fluormica and subsequently formed the fluoramphibole crystals. This reaction can be written in the form of a chemical equation as follows:

$$
\mathrm{KMg}_{3} \mathrm{AlSi}_{3} \mathrm{O}_{10} \mathrm{~F}_{2}+\mathrm{CaO}+\mathrm{Na}_{2} \mathrm{O}+5 \mathrm{SiO}_{2} \longrightarrow \mathrm{KNa}_{2} \mathrm{CaAlMg}_{3} \mathrm{Si}_{8} \mathrm{O}_{22} \mathrm{~F}_{2}
$$



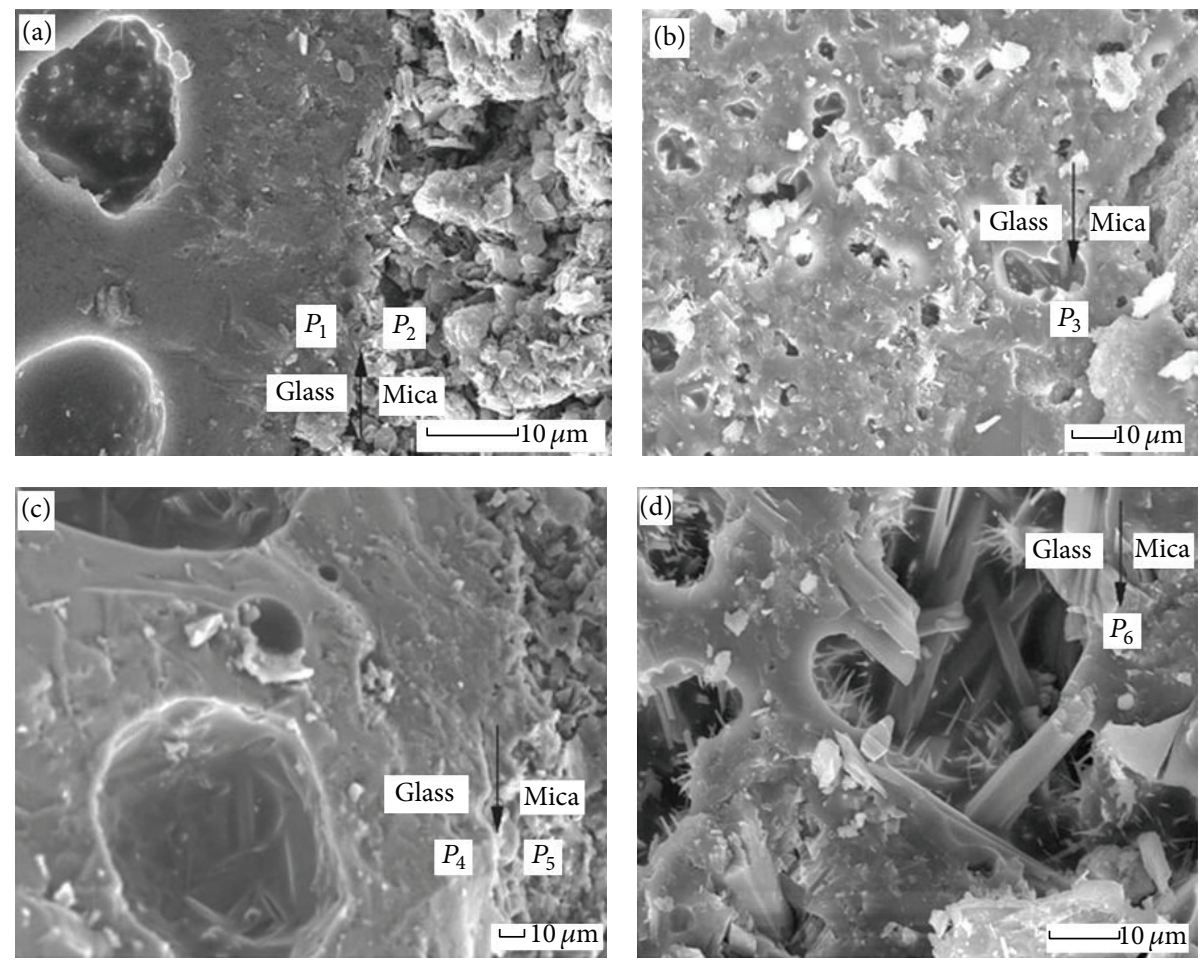

FIGURE 5: Microstructures of the interface in sandwich samples isothermally heated at $820^{\circ} \mathrm{C}$ for (a) 0 and (b) $2 \mathrm{~h}$ and at $900^{\circ} \mathrm{C}$ for (c) 0 and (d) $2 \mathrm{~h}$.
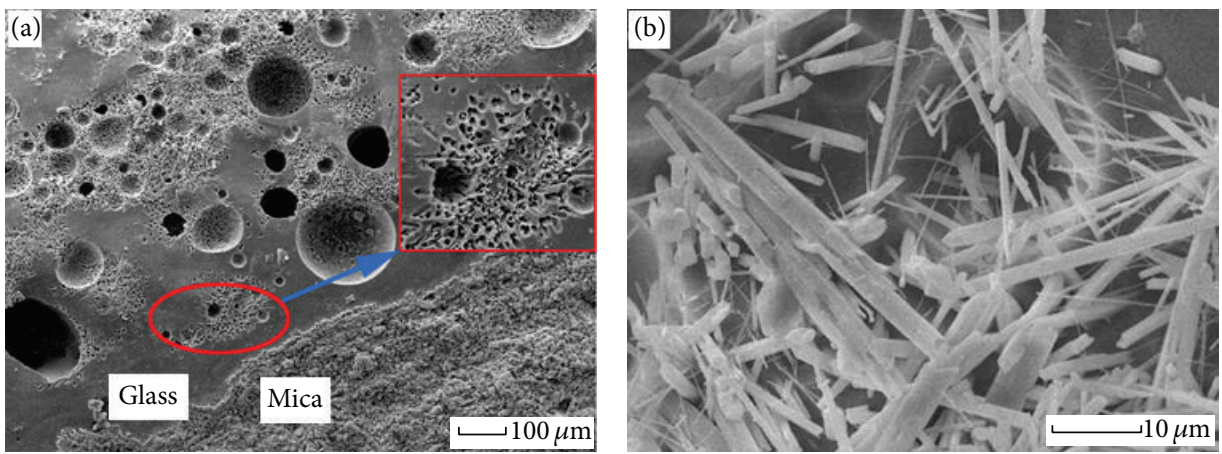

FIGURE 6: Microstructures of the interface in sandwich samples after hydrofluoric acid etching.
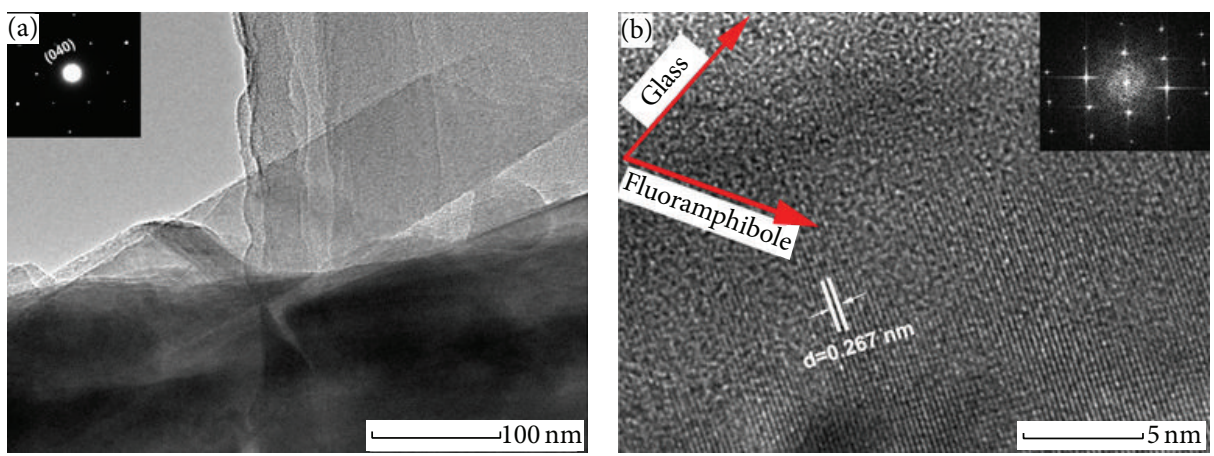

FIGURE 7: TEM (a, inset is the selected area electron diffraction) and HRTEM (b, inset is the fast Fourier transform) photographs of glass in sandwich samples. 


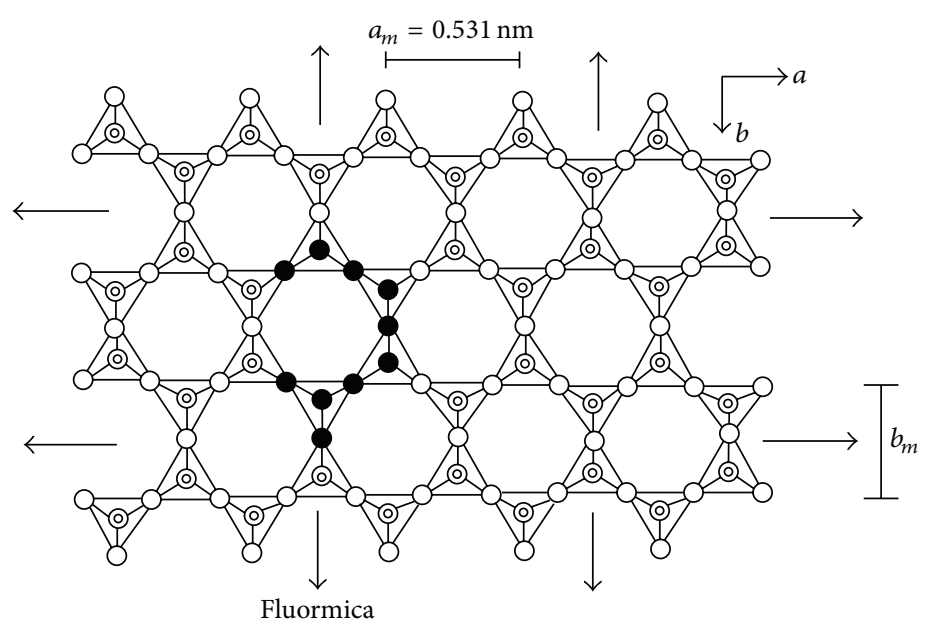

- $\mathrm{O}$ in $\left[\mathrm{Si}_{4} \mathrm{O}_{10}\right]^{4-}$ group

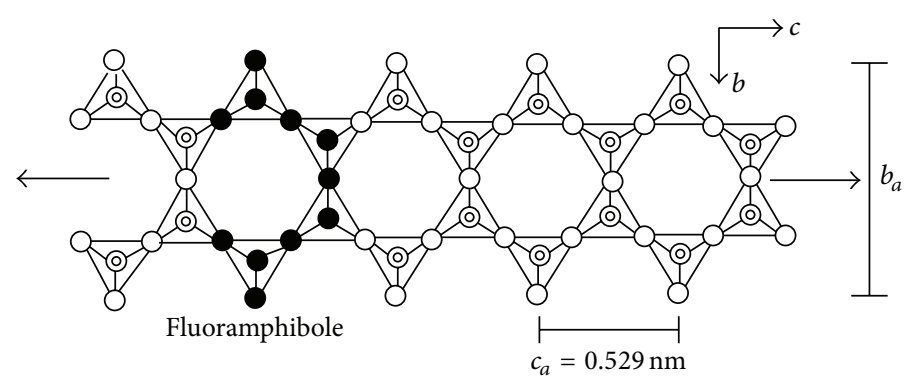

O in $\left[\mathrm{Si}_{4} \mathrm{O}_{11}\right]^{6-}$ group

(a)

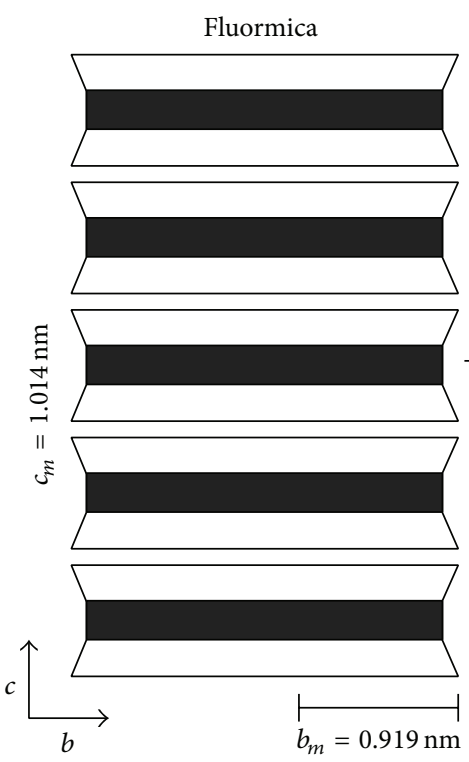

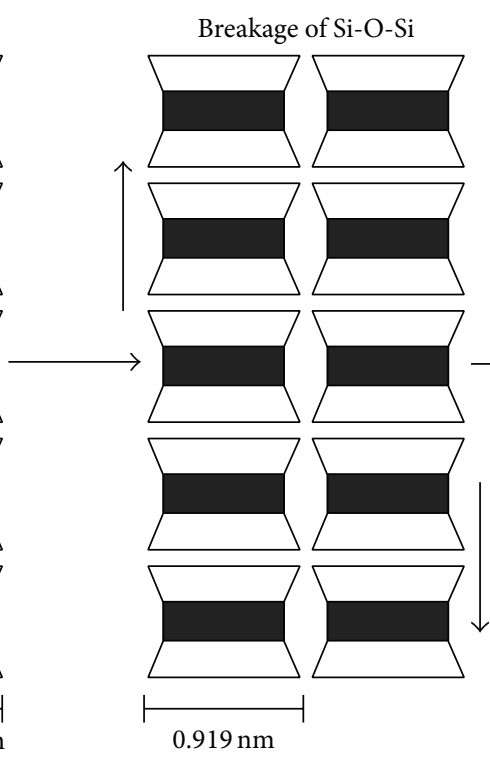

(b)

FIgURE 8: Schematic of transformation from fluormica to fluoramphibole. (a) The sheet and double-chain structures in fluormica and fluoramphibole. (b) Crystallography model of fluormica-fluoramphibole transformation. 
A crystallographic model of fluormica-fluoramphibole transformation can be established. The fluormica crystal has a layered structure, and the silicon oxygen tetrahedrons are connected with one another through the bridge oxygen bonds, which form 2D plane network of Si-O tetrahedron; its lattice constants are $a_{m}=0.531 \mathrm{~nm}, b_{m}=0.919 \mathrm{~nm}$, and $c_{m}=1.014 \mathrm{~nm}$. The fluoramphibole crystals have a doublechain structure; each fluoramphibole crystal cell has two rows of parallel double strands, but the two lines of double strands are not in the same plane. Double chain establishes connection through sodium and calcium ions [11, 12]. The lattice constants of the fluoramphibole crystals are $a_{a}=0.982 \mathrm{~nm}$, $b_{a}=1.792 \mathrm{~nm}$, and $c_{a}=0.529 \mathrm{~nm} ; a_{m} \approx c_{a}, 2 b_{m} \approx b_{a}$, and $c_{m} \approx a_{a}$ (Figure 8(a)).

In the isothermal process at $820^{\circ} \mathrm{C}$, the $\mathrm{O}^{2-}, \mathrm{Na}^{+}$, and $\mathrm{Ca}^{2+}$ ions diffuse into the fluormica crystals. The results indicated that the mean silicon-bridge oxygen ( $\mathrm{Si}-\mathrm{O}-\mathrm{Si}$ ) in the plane network of $\mathrm{Si}-\mathrm{O}$ tetrahedron was disconnected along the $a$-axis with the increase of oxygen contents $[13,14]$. Thus, fluormica will decompose and finally transform to a doublechain structure (Table 1, Figure 3, and Table 2). Two rows of disconnected double strands along the $c$-axis direction of the fluormica crystals occurred at a relative displacement $1 / 4 c$ and transformed into two rows of parallel double chain in fluoramphibole crystals [15]. The double-chain displacement was reconnected by the $\mathrm{Na}^{+}$and $\mathrm{Ca}^{2+}$ ions to form the ion bonds through diffusion into the fluormica crystals; subsequently, fluoramphibole crystals were formed.

Hence, the $c$-axis direction of fluormica crystals was transformed into the $a$-axis direction of fluoramphibole crystals, and the $a$-axis direction of fluormica crystals has been transformed into the $c$-axis direction of fluoramphibole crystals. Nevertheless, the lattice constant and $b$-axis direction of fluormica crystals were unchanged. However, one fluoramphibole crystal cell along $b$-axis direction was transformed from two juxtaposition fluormica crystal cells. Therefore, the fluoramphibole crystal lattice constant $b_{a}$ is twice of the $b_{m}$ of fluormica (Figure 8(b)).

\section{Conclusions}

(1) In the isothermal sintering process, fluormica crystals do not directly change into fluoramphibole crystals. First, these crystals are decomposed and precipitated; $\mathrm{O}^{2-}, \mathrm{Na}^{+}$, and $\mathrm{Ca}^{2+}$ ions diffuse from the glass into the fluormica crystals. The increase of oxygen contents causes the disconnection of the oxygen bridge bond along the $a$-axis from the plane network; consequently, the layered structure changes into a doublechain structure, and fluormica decomposition occurs.

(2) Two rows of disconnected double strands along the $c$ axis direction of the fluormica crystals occur at a relative displacement of $1 / 4 c$ and transform into two rows of parallel double chain in the fluoramphibole crystals. The double-chain displacement is reconnected by the $\mathrm{Na}^{+}$and $\mathrm{Ca}^{2+}$ ions to form bonds through diffusion into the fluormica crystals; subsequently, fluoramphibole crystals are formed.

\section{Competing Interests}

The authors declare that there is no conflict of interests regarding the publication of this paper.

\section{Acknowledgments}

This project is supported by National Natural Science Foundation of China (Grant no. 51308086) and Program for Liaoning Excellent Talents in University (Grant no. LJQ2015020).

\section{References}

[1] G. H. Beall, "Chain silicate glass-ceramics," Journal of NonCrystalline Solids, vol. 129, no. 1-3, pp. 163-173, 1991.

[2] M. Mirsaneh, I. M. Reaney, P. F. James, and P. V. Hatton, "Effect of $\mathrm{CaF}_{2}$ and $\mathrm{CaO}$ substituted for $\mathrm{MgO}$ on the phase evolution and mechanical properties of K-fluorrichterite glass ceramics," Journal of the American Ceramic Society, vol. 89, no. 2, pp. 587595, 2006.

[3] I. L. Denry and J. A. Holloway, "Effect of sodium content on the crystallization behavior of fluoramphibole glass-ceramics," Journal of Biomedical Materials Research Part A, vol. 63, no. 1, pp. 48-52, 2002.

[4] G.-H. Chen and X.-Y. Liu, "Sintering, crystallization and properties of $\mathrm{MgO}-\mathrm{Al}_{2} \mathrm{O}_{3}-\mathrm{SiO}_{2}$ system glass-ceramics containing ZnO," Journal of Alloys and Compounds, vol. 431, no. 1-2, pp. 282-286, 2007.

[5] S. R. Bragança and C. P. Bergmann, "Traditional and glass powder porcelain: technical and microstructure analysis," Journal of the European Ceramic Society, vol. 24, no. 8, pp. 2383-2388, 2004.

[6] E. Bernardo, M. Varrasso, F. Cadamuro, and S. Hreglich, "Vitrification of wastes and preparation of chemically stable sintered glass-ceramic products," Journal of Non-Crystalline Solids, vol. 352, no. 38-39, pp. 4017-4023, 2006.

[7] W. Y. Zhang and H. Gao, "Preparation of machinable fluoramphibole glass-ceramics from soda-lime glass and fluormic," International Journal of Applied Ceramic Technology, vol. 5, no. 4, pp. 412-418, 2008.

[8] W. Y. Zhang, H. Gao, and Y. Xu, "Sintering and reactive crystal growth of diopside-albite glass-ceramics from waste glass," Journal of the European Ceramic Society, vol. 31, no. 9, pp. 1669-1675, 2011.

[9] W.-Y. Zhang, H. Gao, B.-Y. Li, and Q.-B. Jiao, "A novel route for fabrication of machinable fluoramphibole glass-ceramics," Scripta Materialia, vol. 55, no. 3, pp. 275-278, 2006.

[10] J. Rocherullé and P. Bénard-Rocherullé, “The devitrification of a LAS glass matrix studied by X-ray powder diffraction," Solid State Sciences, vol. 4, no. 7, pp. 999-1004, 2002.

[11] D. Y. Pushcharovskiǐ, Y. S. Lebedeva, I. V. Pekov, G. Ferraris, A. A. Novakova, and G. Ivaldi, "Crystal structure of magnesioferrikatophorite," Crystallography Reports, vol. 48, no. 1, pp. 16-23, 2003.

[12] F. C. Hawthorne and R. Oberti, "Amphiboles: crystal chemistry," Reviews in Mineralogy and Geochemistry, vol. 67, no. 1, pp. 1-54, 2007.

[13] J. Najorka and M. Gottschalk, "Crystal chemistry of tremolitetschermakite solid solutions," Physics and Chemistry of Minerals, vol. 30, no. 2, pp. 108-124, 2003. 
[14] D. M. Jenkins, K. N. Bozhilov, and K. Ishida, "Infrared and TEM characterization of amphiboles synthesized near the tremolitepargasite join in the ternary system tremolite-pargasitecummingtonite," American Mineralogist, vol. 88, no. 7, pp. 11041114, 2003.

[15] D. R. Vnnren and P. R. Buseck, "Microstructures and reaction mechanisms in biopyriboles," American Mineralogist, vol. 65, no. 7-8, pp. 599-623, 1980. 

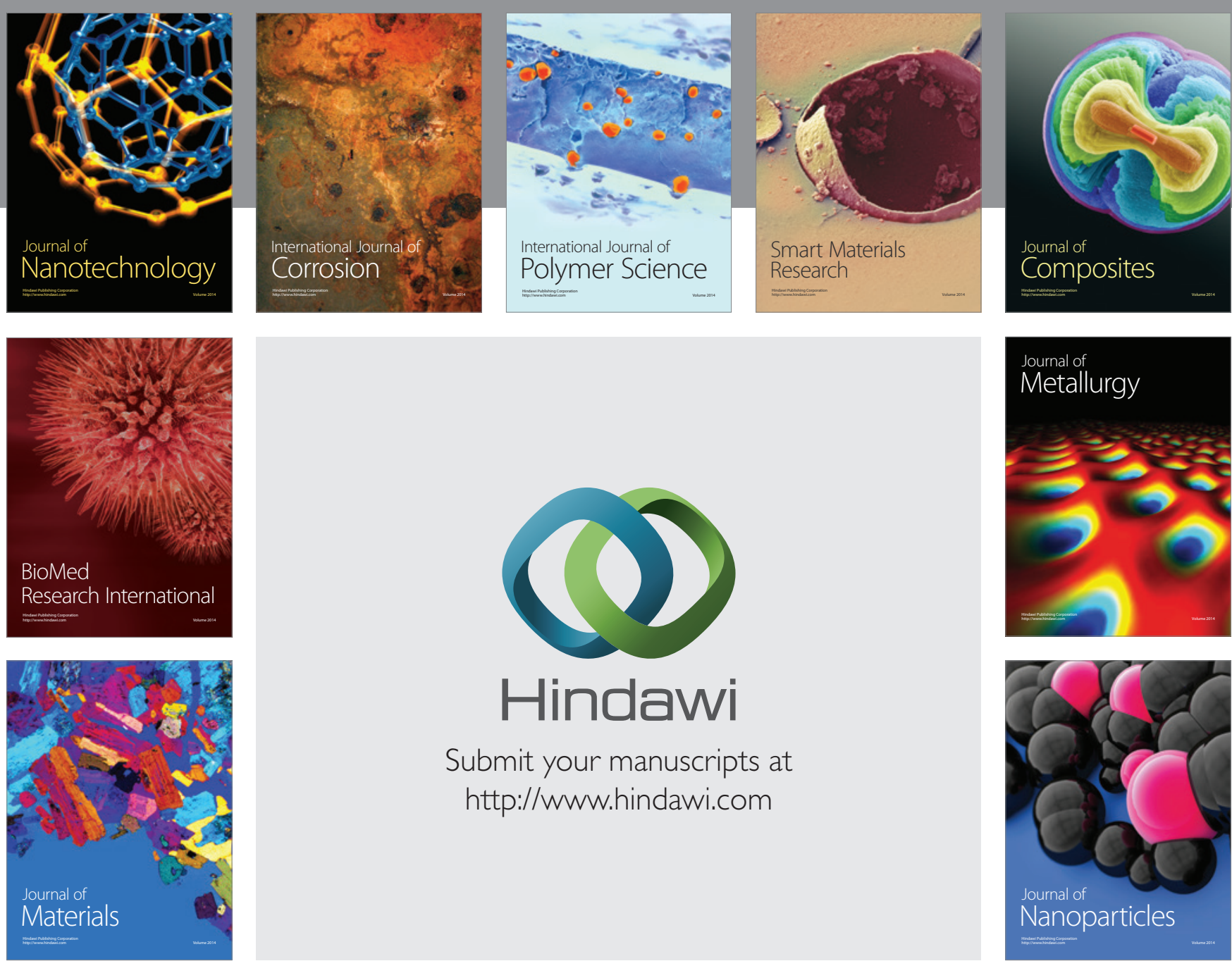

\section{Hindawi}

Submit your manuscripts at

http://www.hindawi.com



Materials Science and Engineering
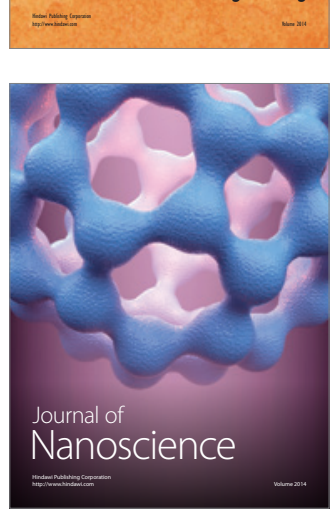
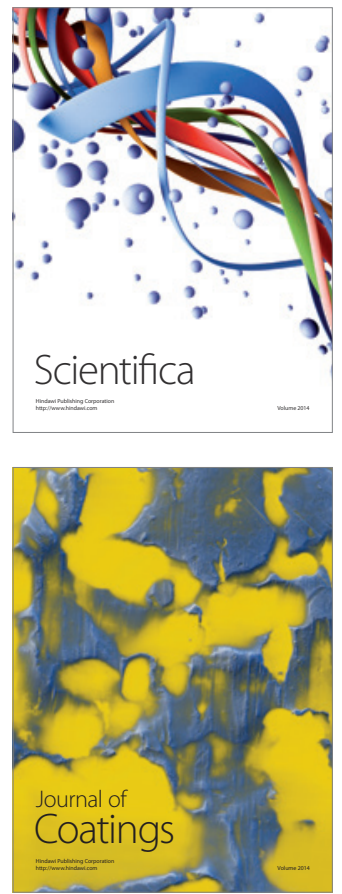
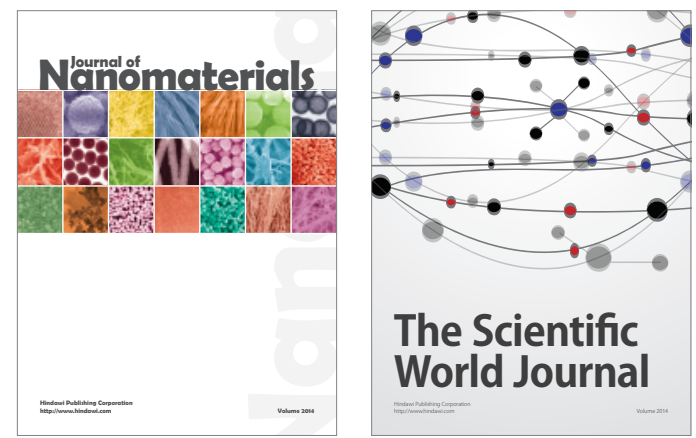

The Scientific World Journal
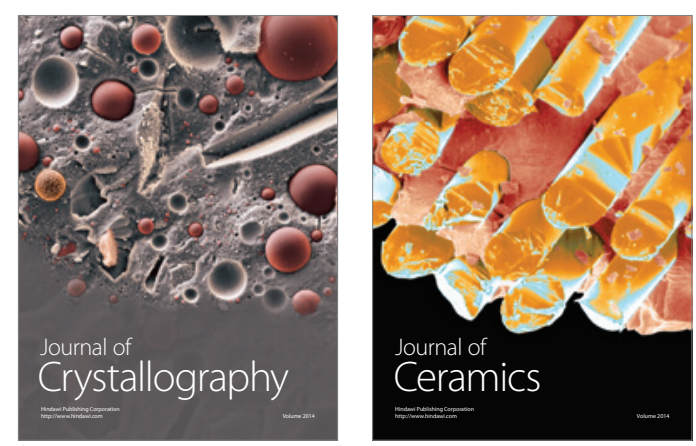
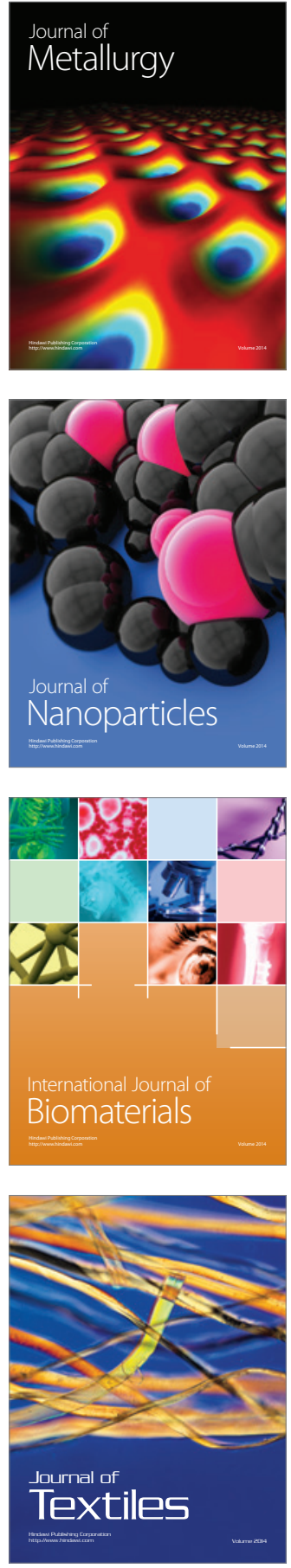